\title{
Pyogenic ventriculitis following urosepsis caused by Escherichia coli
}

\author{
Hiroyuki Kobayashi, Tomoharu Suzuki, Yasuharu Tokuda
}

Department of General Medicine, Mito Medical Center, Tsukuba University Hospital, Mito, Ibaraki, Japan

\section{Correspondence to} Dr Hiroyuki Kobayashi, hrkoba1@gmail.com
To cite: Kobayashi $\mathrm{H}$, Suzuki T, Tokuda Y. BMJ Case Rep Published online: [please include Day Month Year] doi:10.1136/bcr-2013201148

\section{DESCRIPTION}

A 78-year-old woman with the history of spinal stenosis presented to our emergency room by ambulance with the acute onset of back pain and mild altered mental status. On examination, there was knock pain over the right costovertebral angle. Urinalysis showed pyuria and bacteriuria. She was admitted with a diagnosis of urinary tract infection. Empiric treatment was started with intravenous ceftriaxone. An initial CT scan showed bilateral ventricular enlargement (figure 1). Because she had prolonged disturbance of the consciousness, a lumbar puncture was tried with suspected meningeal dissemination; it was failed due to her difficulty in appropriate positioning for the procedure. Surprisingly, repeated CT scan on day 3 after admission showed increased ventricular densities with fluid-debris levels in the dependent portions of the bilateral lateral ventricles (figure 2). A diagnosis of pyogenic ventriculitis complicated by urinary tract infection was considered and emergent bilateral ventricular drainage was performed with good clinical improvement. Cultures of urine, blood and ventricle-drained pus all grew Escherichia coli with the same antibiogram profiles including susceptibility to ceftriaxone in the drug sensitivity test. Pyogenic ventriculitis is rare but can be a serious complication from sepsis including urosepsis. ${ }^{1}{ }^{2}$ Urgent diagnosis and neurosurgical drainage is mandatory for preventing neurological morbidity from this important central nervous system complication from any types of sepsis.



Figure 1 Brain CT scan without contrast enhancement on the day of admission.

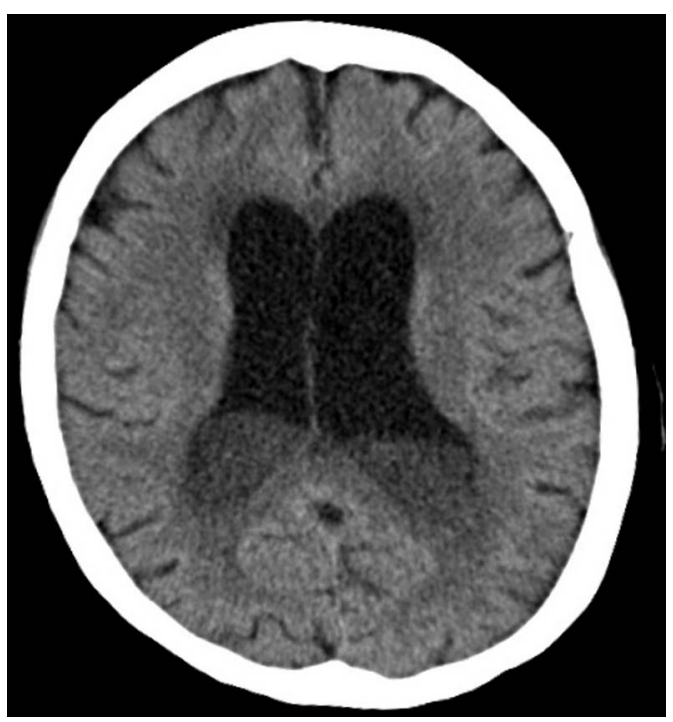

Figure 2 Brain CT scan without contrast enhancement on day 3 after admission.

\section{Learning points}

- It is uncommon but pyogenic ventriculitis is one of the important central nervous system complications from any type of sepsis, which require urgent surgical intervention.

- Images are obvious to show progression of infection.

- Cultures of urine, blood and ventricle-drained pus all grew Escherichia coli with same antibiogram.

Contributors HK and TS mainly took care of the patient during the entire admission and YT contributed in the writing of the manuscript.

Competing interests None.

Patient consent Obtained.

Provenance and peer review Commissioned; internally peer reviewed.

\section{REFERENCES}

1 Hansom D, Littlejohn MG, Clancy MJ. Pyogenic ventriculitis following enteral bacterial translocation in a patient with small bowel obstruction. Scott Med J 2012;57:1-3.

2 Fukui MB, Williams RL, Mudigonda S, et al. CT and MR imaging features of pyogenic ventriculitis. AJNR Am J Neuroradiol 2001;22:1510-16. 
Copyright 2013 BMJ Publishing Group. All rights reserved. For permission to reuse any of this content visit http://group.bmj.com/group/rights-licensing/permissions.

BMJ Case Report Fellows may re-use this article for personal use and teaching without any further permission.

Become a Fellow of BMJ Case Reports today and you can:

- Submit as many cases as you like

- Enjoy fast sympathetic peer review and rapid publication of accepted articles

- Access all the published articles

- Re-use any of the published material for personal use and teaching without further permission

For information on Institutional Fellowships contact consortiasales@bmjgroup.com

Visit casereports.bmj.com for more articles like this and to become a Fellow 